\title{
Evaluation of Oil Content and Fatty Acid Compositions of Flax (Linum usitatissimum L.) Varieties of India
}

\author{
Vikas Pali ${ }^{1} \&$ Nandan Mehta ${ }^{1}$ \\ ${ }^{1}$ Department of Genetics and Plant Breeding, Indira Gandhi Agricultural University, Raipur, India \\ Correspondence: Vikas Pali, Department of Genetics and Plant Breeding, College of Agriculture, Krishak Nagar, \\ Indira Gandhi Agricultural University, Raipur-492012, C.G. India. E-mail: vikaspali21@gmail.com
}

\author{
Received: April 11, 2014 Accepted: June 21, 2014 Online Published: August 15, 2014 \\ doi:10.5539/jas.v6n9p198 URL: http://dx.doi.org/10.5539/jas.v6n9p198
}

\begin{abstract}
Flax (Linum usitatissimum L.) is the third largest natural fiber crop and one of the five major oil crops in the world. An experiment was conducted to evaluate the oil content and fatty acid compositions of flax varieties grown in Chhattisgarh state of India. The oil content ranged from $33.97 \%$ to $42.27 \%$ in the experimental material. The highest oil content was recorded for variety Deepika (42.27\%) followed by Indira Alsi-32 (42.12\%), Sharda $(41.12 \%)$ and Kartika (41.11\%). Two saturated (Palmatic and stearic acid) and three unsaturated fatty acids (Oleic, linoleic and linolenic acid) were identified by gas chromatography represented $12.34 \%$ and $87.65 \%$ of the total oil, respectively. Fatty acid analysis of the flax varieties in our studies showed $33.14 \%$ to $54.82 \%$ of linolenic acid whereas, the mean value of linoleic, oleic, stearic and palmatic acid were $15.88 \%, 27.76 \%, 6.26 \%$ and $6.07 \%$, respectively. The variety RLC-92 (54.82\%) exhibited the highest linolenic acid followed by RLC-134 (53.01\%), R-552 (52.41\%), R-4140 (51.14\%), RLC-122 (51.08\%) and GS-64 (50.49\%) while the lowest linolenic acid was observed in the variety Kiran (33.14\%) followed by Sharda (34.41\%) and Neela (36.85\%). Both genotypic (GCV) and phenotypic coefficients of variation (PCV) were low for oil content and fatty acid components. Linoleic acid exhibited highest GCV (17.52\%) and PCV (17.63\%), respectively. High heritability with moderate genetic advance was observed for oil content and all fatty acid components suggest that selection per se will be rewarding for these traits. Correlation coefficient revealed weak positive association of 1000 seed weight with oil content. Among all the fatty acids, palmatic acid showed significant positive association while linoleic acid showed significant negative association. Results indicated that higher oil content varieties showed higher linolenic acid in flax.
\end{abstract}

Keywords: flax, fatty acids, oil content, linolenic acid, correlation

\section{Introduction}

Plant oils are important macromolecules for both human consumption and for industrial applications. Human consumption accounts for $80 \%$ of oil consumption in the world (Luhs \& Friedt, 1994). Six percent is used as animal feed, and the remaining is used in industrial applications. Flax (Linum usitatissimum L.) is a multi-purpose crop, and its importance is showed by the fact that every part of the plant has specific economic use. The most important flax producing countries are Canada, Argentina, USA, China, India and Europe (Lidefelt, 2007; Wang et al., 2007). Flax occupies an important position in world market because of its technical grade oil, its seeds when crushed yield oil. During the last decade, the interest in flax has been reinvented in modern societies due to increased awareness of omega-3 nutrition, as flax is the richest agricultural source of omega-3 fatty acids. Flax oil is an important nutraceutical and is added in functional foods for helath benefits. The nutritional significance of flax oil is due to the presence of higher levels of $\alpha$-linolenic acid (ALA) of omega-3 fatty acid (O3FA) family. ALA, an essential fatty acid, acts as a precursor for biologically active longer chain polyunsaturated fatty acids (PUFA) of omega-3 class, mainly the Eicosapentaeonic acid (EPA and Docosahexaeonic acid (DHA) (Rajwade et al., 2010).

The quality and utilization of flax oil is determined by its fatty acid composition. In general, flax oil has a high level of linolenic acid (35-66\%), which imparts it the property of drying oil, suitable for manufacturing paints, stains, inks, varnishes and linoleum etc (Gill, 1987). In India, 25\% of total flax oil is still consumed for edible purpose. High levels of linolenic acid render it unfit for consumption as edible oil due to undesirable odors and flavour reversion associated with the auto-oxidation (Green, 1986a; Graef et al., 1988). But flax oil is the richest 
plant source of linoleic (Omega-6) and linolenic (Omega-3) polyunsaturated fatty acids (PUFA), which are essential for humans since they cannot be synthesized in the organism and must be ingested in food but its oil is qualitatively different from the more common vegetable oils with high PUFA proportions, such as soya oil, sunflower oil, rape oil, olive oil, etc. The linolenic acid in flax oil is 5.5 times more than the sources containing the highest level (Bloedon \& Szapary, 2004). This essential fatty acid can be metabolized to Eicosapentaenoic acid (EPA) and Docosahexaenoic acid (DHA) by several enzymes in human intestine system (Chen et al., 2002). It is well known that linolenic acid increases the absorption of long chain-polyunsaturated fatty acids (LCPUFA), especially EPA and DHA, and decreases the risk of several diseases (Visentainer et al., 2005). Recently, there has been a growing interest in the probiotic properties of flax and its beneficial effects on coronary heart disease, some kinds of cancer and neurological and hormonal disorders (Huang \& Milles, 1996; Huang \& Ziboh, 2001; Simopoulos, 2002), colon tumor (Dwivedi et al., 2005), breast cancer (Chen et al., 2006; Thompson et al., 1996) and atherosclerosis (Wang et al., 2005; Prasad, 1997). There are very few published reports of oil content and fatty acid composition of flax varieties grown in India which has become essential nowadays to market the produce in terms of nutritional value and quality. Further, variability in oil content and fatty acid composition helps in selection of parents for modified oil breeding programs. Therefore, the present study was conducted to evaluate oil content and fatty acid compositions (especially omega-3 fatty acid) of flax varieties grown in Chhattisgarh state of India.

\section{Materials and Methods}

The experimental material comprised of 48 flax varieties (Table 1). All these varieties were grown in the field condition using a Randomized Complete Block Design with three replications during rabi season, 2011-12 at Research cum Instructional Farm, Department of Genetics and Plant Breeding, College of Agriculture, Indira Gandhi Agricultural University, Raipur, India. Seed samples were taken at maturity and oil content was determined by a wide line nuclear magnetic resonance (NMR). About $2 \mathrm{~g}$ of oven dried seeds were analyzed by NMR (Newport analyser) with reference to a standard of extracted flax oil at oilseed section of Department of Biochemistry, Directorate of Oilseed Research, Hyderabad. Fatty acids were analyzed by GC equipped with capillary column. The seeds were oven-dried at $40{ }^{\circ} \mathrm{C}$ for 4 hours, using a hot air oven, up to moisture content of about $5 \%$. Flax seeds were powdered in mortar and pestle and $100 \mathrm{mg}$ powder was esterified using $4 \mathrm{ml}$ methenolic-HCL and extracted in $3 \mathrm{ml}$ hexane. The hexane extracts were dried in argon current and reconstituted in 1:50 volumes of chloroform (Manku et al., 1983). $1 \mu 1$ of this extract was injected in Autosystem XL GC (Perkin Elmer, USA) with SP-2330 Supelco capillary column, 30 meter long and $0.32 \mathrm{~mm}$ diameter. The temperature program was $150{ }^{\circ} \mathrm{C}$ for $10 \mathrm{~min}$, followed by $10^{\circ} \mathrm{C}$ rises per min up to $220^{\circ} \mathrm{C}$ and steady for $10 \mathrm{~min}$ Helium $1 \mathrm{ml}$ per min was used as the carrier gas. The injector port was maintained at $240{ }^{\circ} \mathrm{C}$ and FID detector temperature was $275^{\circ} \mathrm{C}$. Appropriate fatty acid standards were procured from Sigma Aldrich (USA) and the fatty acid peaks were identified by integrating them with the satndards' profiles. The area under the peak was expressed as percentage fatty acid content. Estimation of each sample was repeated minimum three times.

\section{Results and Discussion}

\subsection{Oil Content}

Large variation was observed for oil content in flax varieties under study (Table 1). The oil content ranged from $33.97 \%$ to $42.27 \%$ with a mean value of $38.41 \%$ (Table 2). The highest oil content was recorded for Deepika (42.27\%) followed by Indira Alsi-32 (42.12\%), Sharda (41.12\%) and Kartika (41.11\%) while the lowest was observed in Neela (33.97\%) and LC-54 (35.81\%), respectively. The effect of oil content on linolenic acid is depicted in Figure 1. Flax has been reported to contain about $40 \%$ oil in the seed (Choo et al., 2007). However several findings have reported variation ranging from $23.28 \%$ to $46 \%$ in seeds of different flax varieties and under different agro-climatic zones (Green \& Marshall, 1981; El-Beltagi et al., 2007; Bayrak et al., 2010; El-Beltagi et al., 2011). Diederichsen and Fu (2008) analyzed world collection of 2934 lines from 72 countries and observed a mean of $38.3 \%$ with wide range of variation from 31.4 to $45.7 \%$ for oil content in flax. The present study is in agreement with Diederichsen and Fu (2008) for mean oil content however, we observed narrow range of variation due to small number of varieties under evaluation. 


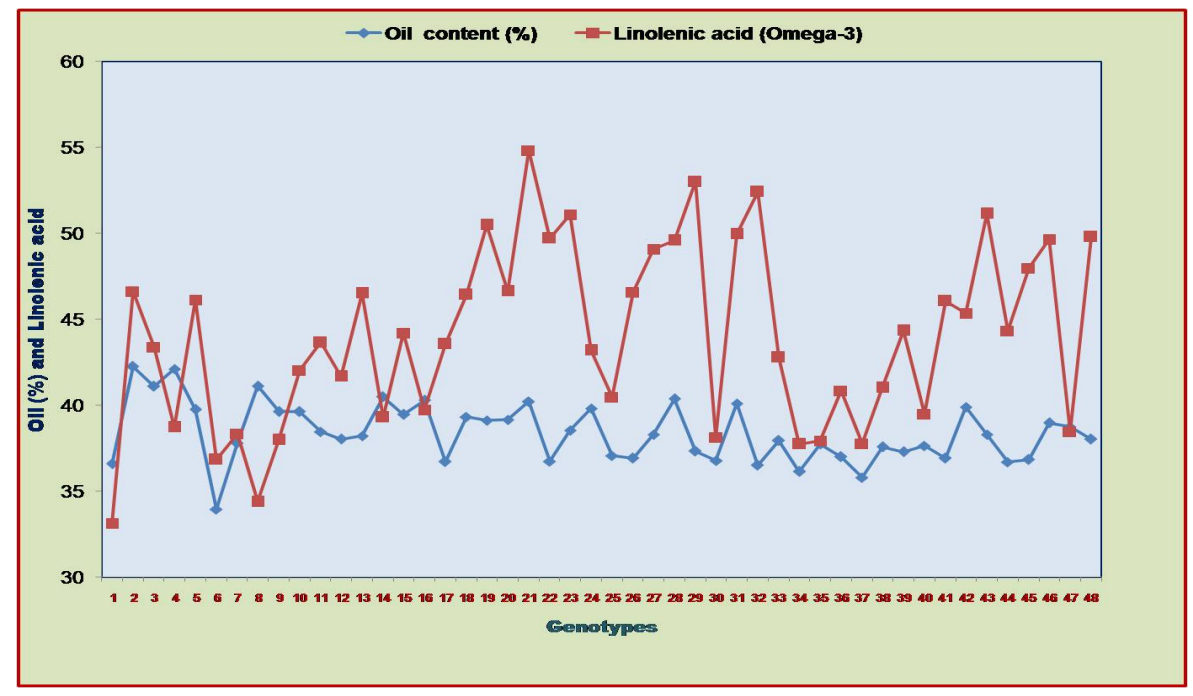

Figure 1. Effect of oil content on linolenic acid (Omega-3)

\subsection{Fatty Acid Composition}

Fatty acid analysis of the flax seeds showed presence of five major fatty acids with predominance of 18 carbon species, $\alpha$-linolenic acid (ALA 18:3), linoleic acid (LA 18:2), oleic acid (OA 18:1), steraic acid (SA 18:0) and palmitic acid (PA 16:0), all of which are members of the same pathway catalyzed by the elongase and desaturase enzymes. The comparison of fatty acid was cultivar dependent (Table 1). The amount of total unsaturated fatty acids in selected varieties was $83.78 \%$ to $89.97 \%$ while the amount of total saturated fatty acids ranged from $10.02 \%$ to $16.22 \%$ of the total oil. There are several reports of total unsaturated and saturated fatty acids in flax varieties varying from $87 \%$ to $91 \%$ and $9 \%$ to $12 \%$, respectively (Bhatty, 1995; Choo et al., 2007; El-Beltagi et al., 2007; El-Beltagi et al., 2011).

The unique feature of flax is the accumulation of large amounts of linolenic acid (Omega 3), the final product of three desaturation steps. Fatty acid analysis of the flax varieties grown in Chhattisgarh state of India in our study showed $33.14 \%$ to $54.82 \%$ linolenic acid whereas, the mean value of linoleic, oleic, stearic and palmatic acid were $15.88 \%, 27.76 \%, 6.26 \%$ and $6.07 \%$, respectively (Table 2). These results are in agreement with Diederichsen and $\mathrm{Fu}(2008)$ for linoleic, stearic and palmatic acid but, we observed higher values for oleic acid and lower values for linolenic acid. Green (1986 b) also observed high oleic acid content in segregating generations of mutant lines. The variety RLC-92 (54.82\%) exhibited the highest linolenic acid followed by RLC-134 (53.01\%), R-552 (52.41\%), R-4140 (51.14\%), RLC-122 (51.08\%) and GS-64 (50.49\%) while the lowest linolenic acid was observed in the variety Kiran (33.14\%) followed by Sharda (34.41\%) and Neela $(36.85 \%)$. There are several earlier studies with similar results in different regions of world (Robbelen et al., 1989; Bhatty, 1995; Baydar \& Turgut, 1999; Van Ruth et al., 2001; Bean \& Leeson, 2002; Krist et al., 2006).

Table 1. Oil percentage and fatty acid composition of flax varieties

\begin{tabular}{lllllllllll}
\hline S.No & Varieties & TW & OC (\%) & PA (\%) & SA (\%) & TS (\%) & OA (\%) & LA (\%) & LLA (\%) & TUS (\%) \\
\hline 1 & Kiran & 5.03 & 36.60 & 6.16 & 6.12 & 12.28 & 34.60 & 19.98 & 33.14 & 87.72 \\
2 & Deepika & 6.23 & 42.27 & 5.51 & 5.97 & 11.48 & 25.60 & 16.33 & 46.63 & 88.51 \\
3 & Kartika & 5.43 & 41.11 & 6.77 & 5.09 & 11.86 & 27.30 & 17.42 & 43.39 & 88.14 \\
4 & Indira Alsi-32 & 5.80 & 42.12 & 7.57 & 6.91 & 14.48 & 28.20 & 18.55 & 38.74 & 85.52 \\
5 & Shekhar & 8.53 & 39.76 & 6.12 & 7.38 & 13.5 & 26.30 & 14.08 & 46.13 & 86.50 \\
6 & Neela & 6.33 & 33.97 & 6.42 & 6.76 & 13.18 & 30.50 & 19.49 & 36.85 & 86.82 \\
7 & Rashmi & 5.10 & 37.82 & 5.69 & 6.06 & 11.75 & 29.50 & 20.41 & 38.36 & 88.25 \\
8 & Sharda & 8.07 & 41.12 & 6.50 & 6.24 & 12.74 & 31.80 & 21.04 & 34.41 & 87.26 \\
9 & Meera & 7.03 & 39.65 & 6.32 & 9.90 & 16.22 & 32.60 & 13.19 & 38.00 & 83.78 \\
10 & PKDL-43 & 5.53 & 39.65 & 6.07 & 5.07 & 11.14 & 27.60 & 19.25 & 42.04 & 88.85 \\
\hline
\end{tabular}




\begin{tabular}{|c|c|c|c|c|c|c|c|c|c|c|}
\hline 11 & PKDL-58 & 4.43 & 38.48 & 6.30 & 6.71 & 13.01 & 30.80 & 12.52 & 43.66 & 86.99 \\
\hline 12 & PKDL-62 & 4.83 & 38.04 & 5.94 & 4.62 & 10.56 & 30.20 & 17.55 & 41.69 & 89.44 \\
\hline 13 & JRF-5 & 5.03 & 38.22 & 6.21 & 7.41 & 13.62 & 26.00 & 13.81 & 46.53 & 86.38 \\
\hline 14 & JLS-9 & 7.40 & 40.50 & 5.91 & 7.11 & 13.02 & 33.70 & 14.02 & 39.31 & 86.98 \\
\hline 15 & KL-1 & 4.27 & 39.48 & 6.07 & 6.22 & 12.29 & 29.60 & 13.79 & 44.20 & 87.55 \\
\hline 16 & KL-168 & 4.80 & 40.28 & 6.78 & 6.61 & 13.39 & 32.80 & 14.08 & 39.75 & 86.61 \\
\hline 17 & GS-27 & 4.90 & 36.74 & 6.43 & 6.94 & 13.37 & 27.80 & 15.25 & 43.57 & 86.63 \\
\hline 18 & GS-61 & 7.77 & 39.34 & 6.30 & 7.51 & 13.81 & 26.10 & 13.65 & 46.45 & 86.19 \\
\hline 19 & GS-64 & 6.73 & 39.12 & 6.01 & 5.77 & 11.78 & 19.80 & 17.94 & 50.49 & 88.22 \\
\hline 20 & GS-129 & 6.23 & 39.18 & 5.99 & 6.29 & 12.28 & 25.50 & 15.59 & 46.64 & 87.71 \\
\hline 21 & RLC-92 & 6.57 & 40.23 & 5.51 & 4.78 & 10.29 & 19.00 & 15.91 & 54.82 & 89.72 \\
\hline 22 & RLC-94 & 5.50 & 36.74 & 5.51 & 4.87 & 10.38 & 28.10 & 11.84 & 49.71 & 89.62 \\
\hline 23 & RLC-122 & 6.43 & 38.55 & 6.62 & 7.21 & 13.83 & 23.10 & 12.00 & 51.08 & 86.16 \\
\hline 24 & RLC-123 & 7.03 & 39.82 & 5.83 & 7.39 & 13.22 & 26.40 & 17.20 & 43.21 & 86.78 \\
\hline 25 & RLC-128 & 5.10 & 37.08 & 5.91 & 4.87 & 10.78 & 29.90 & 18.88 & 40.48 & 89.22 \\
\hline 26 & RLC-129 & 5.57 & 36.93 & 5.94 & 5.69 & 11.63 & 25.90 & 15.90 & 46.59 & 88.38 \\
\hline 27 & RLC-132 & 8.63 & 38.31 & 6.15 & 7.79 & 13.94 & 22.90 & 14.05 & 49.09 & 86.06 \\
\hline 28 & RLC-133 & 7.13 & 40.38 & 5.26 & 5.21 & 10.47 & 22.40 & 17.56 & 49.60 & 89.52 \\
\hline 29 & RLC-134 & 7.20 & 37.34 & 5.51 & 5.88 & 11.39 & 21.50 & 14.11 & 53.01 & 88.61 \\
\hline 30 & RLC-135 & 6.8 & 36.80 & 5.81 & 6.27 & 12.08 & 29.40 & 20.43 & 38.14 & 87.92 \\
\hline 31 & RLC-137 & 6.00 & 40.11 & 5.74 & 5.92 & 11.66 & 22.90 & 15.52 & 49.97 & 88.34 \\
\hline 32 & R-552 & 5.00 & 36.52 & 5.97 & 6.08 & 12.05 & 23.10 & 12.46 & 52.41 & 87.94 \\
\hline 33 & CI-229 & 5.63 & 37.96 & 6.16 & 6.52 & 12.68 & 26.50 & 18.06 & 42.79 & 87.33 \\
\hline 34 & NL-97 & 6.4 & 36.15 & 5.40 & 5.69 & 11.09 & 36.50 & 14.67 & 37.76 & 88.91 \\
\hline 35 & Polf-22 & 5.27 & 37.76 & 5.93 & 4.56 & 10.49 & 28.20 & 23.36 & 37.94 & 89.50 \\
\hline 36 & $\mathrm{~T}-397$ & 5.00 & 37.01 & 7.17 & 7.29 & 14.46 & 28.10 & 16.64 & 40.85 & 85.55 \\
\hline 37 & LC-54 & 5.9 & 35.81 & 6.33 & 7.27 & 13.60 & 35.50 & 13.17 & 37.77 & 86.40 \\
\hline 38 & LCK-88068 & 6.00 & 37.59 & 6.41 & 5.90 & 12.31 & 29.90 & 16.76 & 41.04 & 87.68 \\
\hline 39 & FRW-12 & 6.13 & 37.30 & 6.02 & 6.27 & 12.29 & 31.20 & 12.13 & 44.36 & 87.71 \\
\hline 40 & Gcwargi 1-2 & 5.70 & 37.66 & 6.31 & 7.03 & 13.34 & 29.40 & 17.79 & 39.50 & 86.67 \\
\hline 41 & R-2678 & 6.10 & 36.94 & 5.58 & 4.44 & 10.02 & 25.60 & 18.26 & 46.07 & 89.97 \\
\hline 42 & R-4129 & 6.13 & 39.91 & 5.02 & 6.26 & 11.28 & 31.20 & 12.13 & 45.36 & 88.72 \\
\hline 43 & R-4140 & 8.37 & 38.30 & 5.56 & 6.95 & 12.51 & 24.00 & 12.36 & 51.14 & 87.50 \\
\hline 44 & $\mathrm{R}-4141$ & 7.43 & 36.72 & 6.02 & 5.80 & 11.82 & 29.80 & 14.03 & 44.33 & 88.18 \\
\hline 45 & R-4152 & 7.00 & 36.85 & 5.41 & 5.33 & 10.74 & 27.20 & 14.09 & 47.98 & 89.26 \\
\hline 46 & R-4154 & 7.87 & 38.98 & 6.20 & 5.86 & 12.06 & 25.50 & 12.76 & 49.65 & 87.94 \\
\hline 47 & $\mathrm{R}-4158$ & 7.63 & 38.76 & 7.62 & 7.25 & 14.87 & 30.80 & 15.84 & 38.47 & 85.13 \\
\hline 48 & R-4168 & 5.77 & 38.04 & 5.61 & 5.75 & 11.36 & 22.70 & 16.11 & 49.79 & 88.63 \\
\hline
\end{tabular}

TW: 1000 seed weight; OC: Oil content; PA: Palmatic acid (C 16:0); SA: Stearic acid (C 18:0); TS: Total saturated fatty acids; OA: Oleic acid (C 18:1); LA: Linoleic acid (C 18:2); LLA: Linolenic acid (C 18:3); TUS: Total unsaturated fatty acids.

* Note - All observations of oil content and fatty acid compositions are the mean value of three replicated trials.

\subsection{Genetic Parameters \& Association Analysis}

Both genotypic (GCV) and phenotypic coefficients of variation (PCV) were low for oil content and fatty acid components (Table 2). Linoleic acid exhibited highest GCV (17.52\%) and PCV (17.63\%), respectively. The genotypic coefficient of variation (GCV) ranged from oil content $(4.42 \%)$ to linoleic acid $(17.52 \%)$. The phenotypic coefficient of variation and genotypic coefficient of variation for oleic acid is equal whereas, 
linolenic acid, linoleic acid, stearic acid, oil content showed very less difference indicating the greater role of genetic factors in expression of these traits. Differences between genotypic coefficient of variation and phenotypic coefficient of variation were observed for 1000 seed weight indicating higher environmental influences. High heritability with moderate genetic advance was observed for oil content and all fatty acid components. The values of genotypic coefficient of variation for all traits were almost equal in comparison to phenotypic coefficient of variation which clearly indicated high variability and supplementary nature of oil content and fatty acid components. Further, high heritability coupled with moderate genetic advance for these traits suggest that selection per se will be rewarding for these traits.

Table 2. Mean, range, coefficient of variation for oil content and fatty acid components in flax

\begin{tabular}{llllllll}
\hline Characters & Mean & Range & PCV (\%) & GCV (\%) & $\begin{array}{l}\text { Heritability bs } \\
(\%)\end{array}$ & $\begin{array}{l}\text { Genetic advance } \\
(\mathrm{GA})\end{array}$ & GA as\% of mean \\
\hline Seed weight (g) & 6.50 & $9.1-3.6$ & 14.00 & 12.30 & 77.14 & 1.47 & 22.67 \\
Oil content (\%) & 38.41 & $42.27-33.97$ & 4.56 & 4.42 & 94.14 & 16.40 & 42.69 \\
Palmitic acid (\%) & 6.07 & $7.74-5$ & 8.99 & 8.57 & 90.93 & 1.02 & 16.85 \\
Stearic acid (\%) & 6.26 & $10-4.34$ & 16.66 & 16.36 & 96.33 & 2.07 & 33.08 \\
Oleic acid (\%) & 27.76 & $36.62-18.91$ & 14.27 & 14.27 & 99.87 & 8.15 & 29.37 \\
Linoleic acid (\%) & 15.88 & $23.74-11.72$ & 17.63 & 17.52 & 98.69 & 5.69 & 35.86 \\
Linolenic acid (\%) & 44.01 & $54.82-33.14$ & 11.99 & 11.94 & 99.12 & 22.77 & 51.73 \\
\hline
\end{tabular}

Table 3. Correlation coefficients between oil content and fatty acid components in flax

\begin{tabular}{|c|c|c|c|c|c|c|}
\hline Characters & Seed weight (g) & Oil content $(\%)$ & Palmitic acid (\%) & Steraic acid $(\%)$ & Oleic acid (\%) & Linoleic acid (\%) \\
\hline Oil content $(\%)$ & 0.200 & & & & & \\
\hline Palmitic acid (\%) & -0.097 & 0.117 & & & & \\
\hline Stearic acid (\%) & $0.293 *$ & 0.099 & $0.432 * *$ & & & \\
\hline Oleic acid (\%) & -0.220 & -0.210 & 0.239 & 0.204 & & \\
\hline Linoleic acid (\%) & -0.172 & -0.000 & 0.107 & $-0.358 * *$ & 0.065 & \\
\hline Linolenic acid (\%) & 0.212 & 0.126 & $-0.423 * *$ & -0.204 & $-0.851 * *$ & $-0.521 * *$ \\
\hline
\end{tabular}

*,** Significant at 5\% and $1 \%$ level, respectively.

The correlation values between 1000-seed weight, oil content and fatty acid components are presented in Table 3 and the relationship between seed weight, oil content and fatty acid composition are depicted in Figures 2 to 6 . The results revealed weak positive association of 1000 seed weight with oil content. Lower values of seed weight along with oil content were observed in fiber flax varieties and both the trait values increased in dual purpose as well as seed type genotypes. Diederichsen and Fu (2008) also reported increase in seed weight, oil concentration and oil amount per seed. Among all the fatty acids, palmatic acid showed significant positive association while linoleic acid showed significant negative association. Palmatic and stearic acid had weak non-significant positive association with oil content. However, Bayark et al. (2010) observed positive association between palmatic acid and oil content. Significant positive association was observed between stearic and palmatic acid. Linolenic acid observed significant negative association with palmatic, oleic and linoleic acid. 


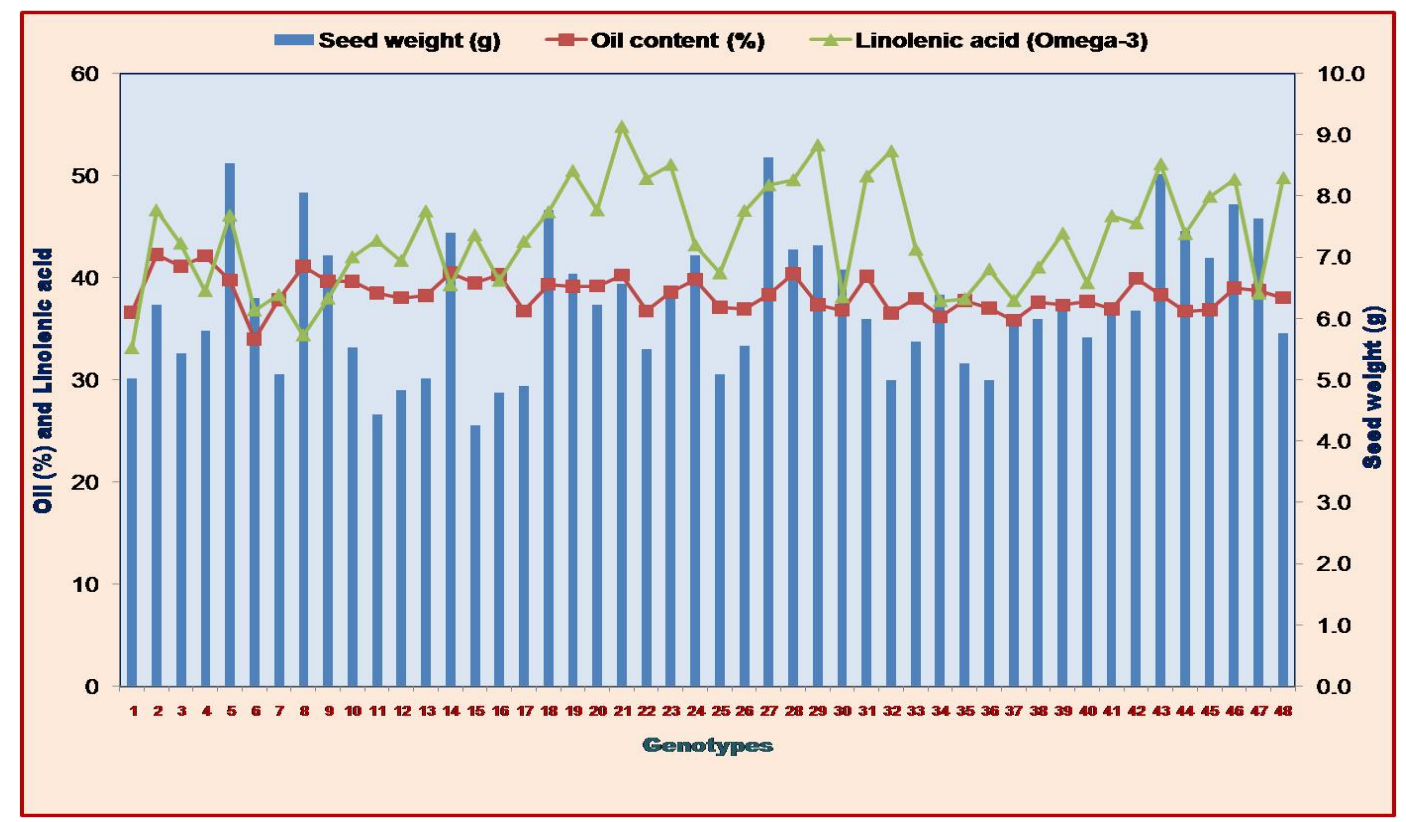

Figure 2. Relationship between seed weight, oil content and linolenic acid (Omega-3)

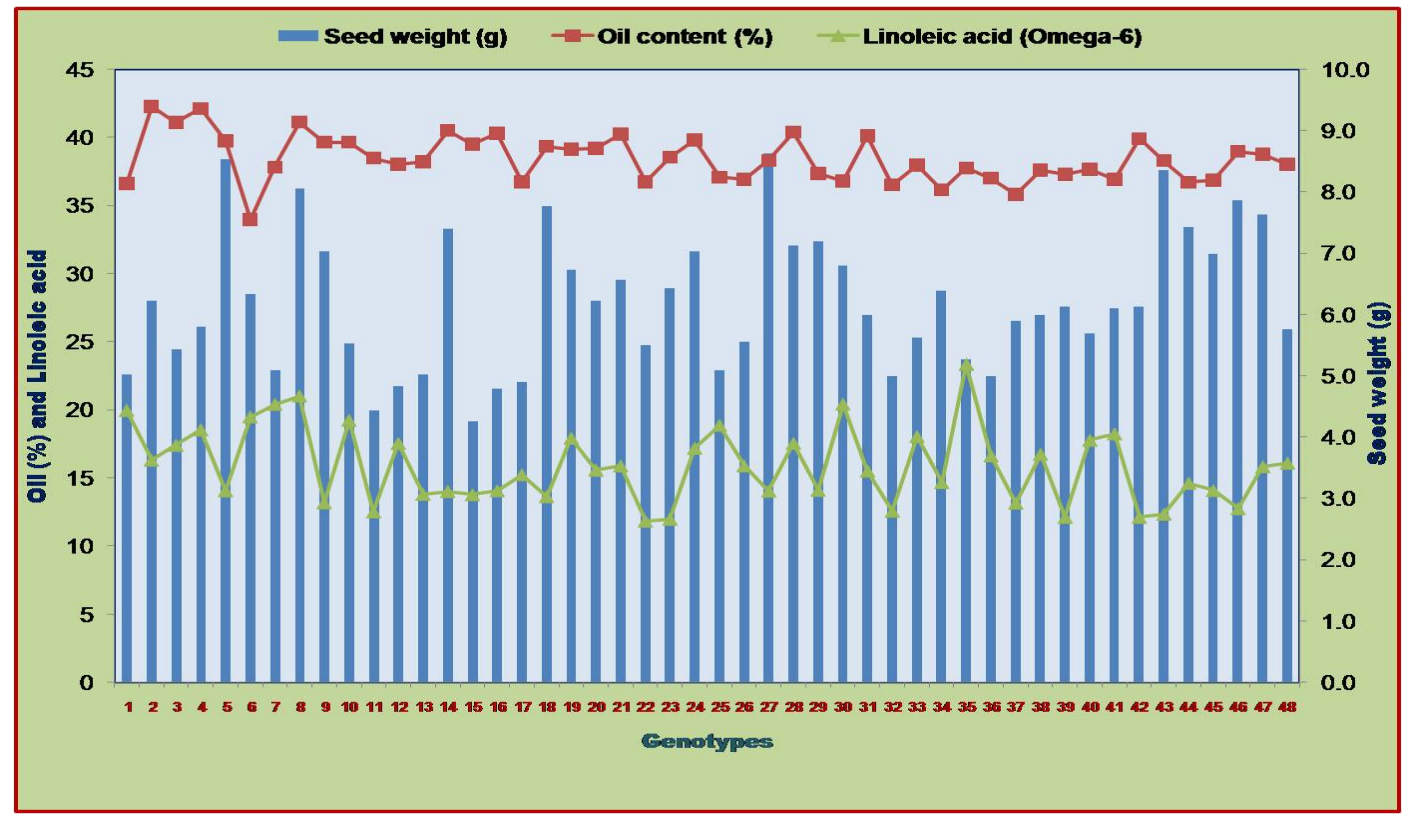

Figure 3. Relationship between seed weight, oil content and linoleic acid (Omega-6) 


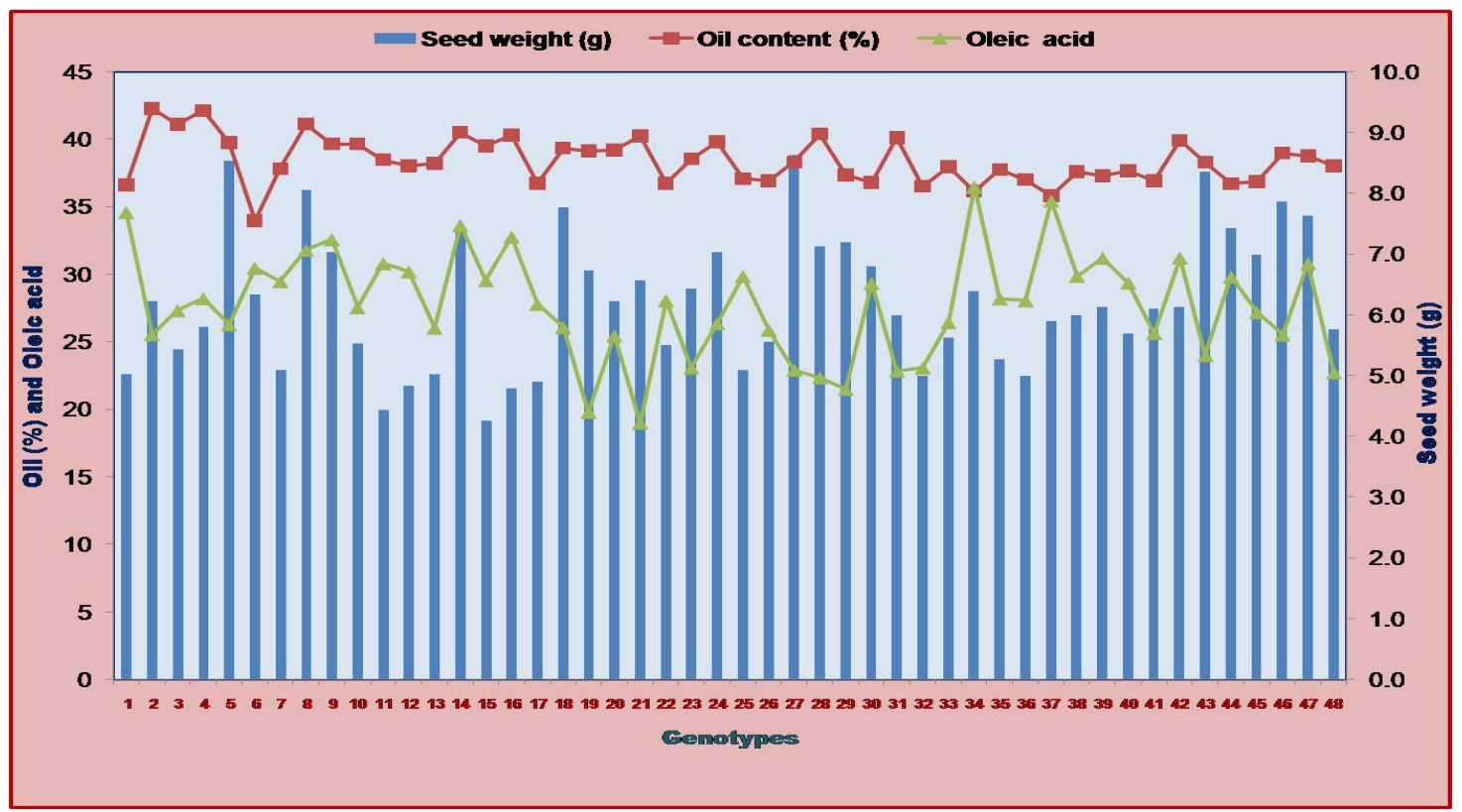

Figure 4. Relationship between seed weight, oil content and oleic acid

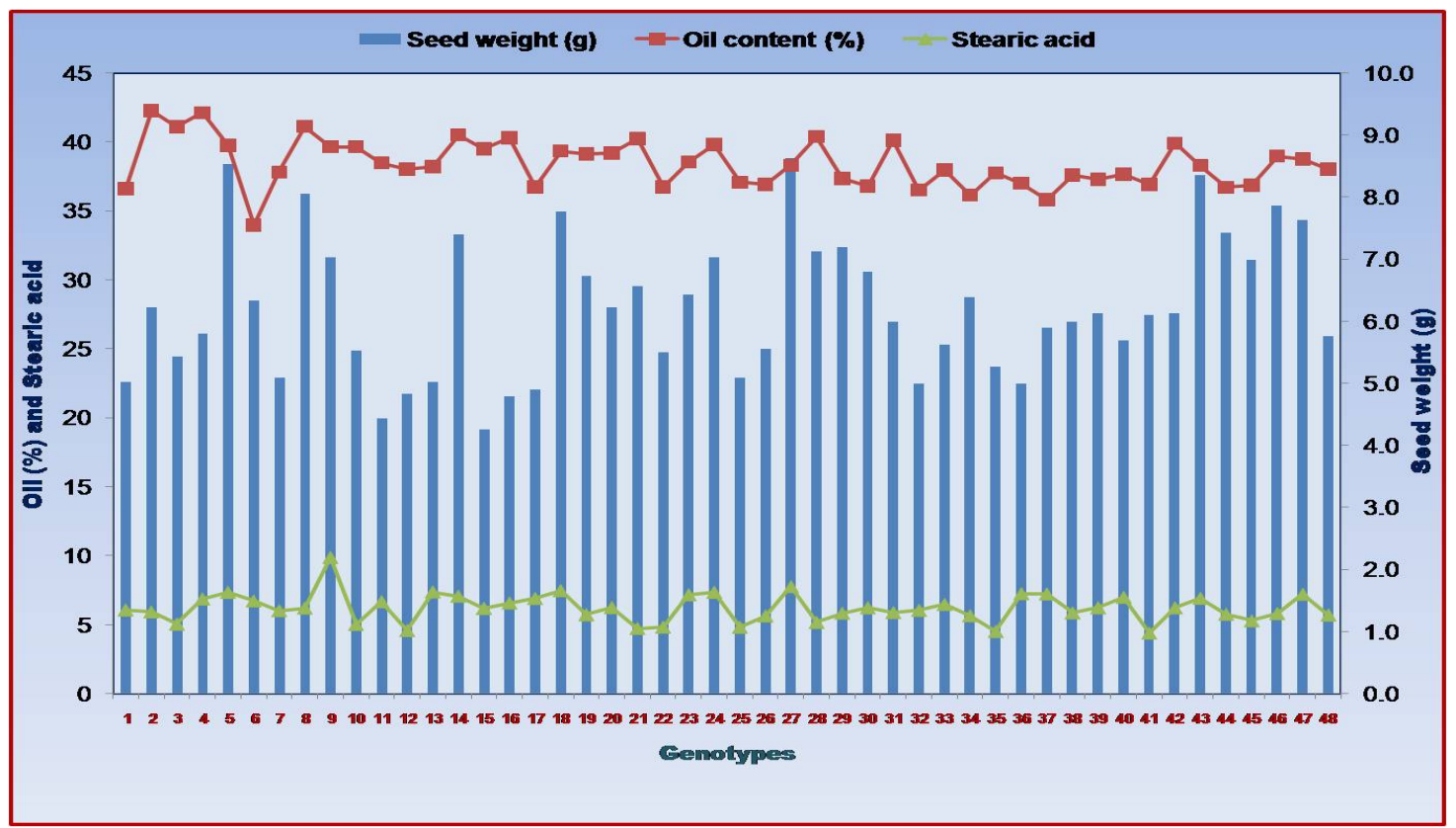

Figure 5. Relationship between seed weight, oil content and stearic acid 


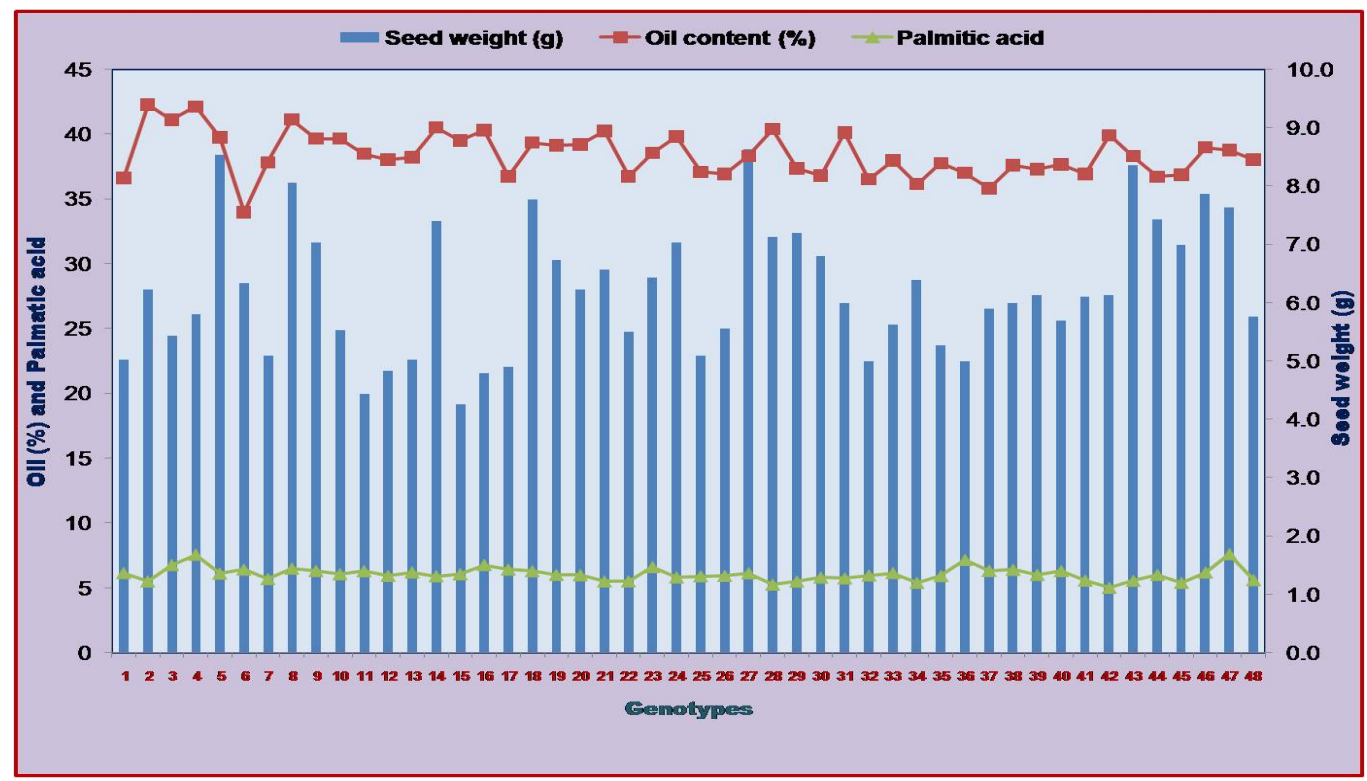

Figure 6. Relationship between seed weight, oil content and palmatic acid

These results explained that high oil content will result in low palmatic acid while increase in linolenic acid will result in decrease in palmatic, oleic and linoleic acids. So, the present study clearly indicated that increase in oil content of varieties will definately enhances the linolenic acid. Bayrak et al. (2010) and Bhatty (1995) also observed negative association of linoleic, oleic and stearic acid with linolenic acid. The association analysis results suggested that selection for increased oil content will not affect the quality of linseed oil except decrease in palmatic acid.

\section{Conclusion}

The results of present study demonstrated that the oil content and fatty acid composition of flax varieties grown in Chhattisgarh state of India were quite similar to studies conducted in other regions. Large variation was observed for oil content and fatty acid composition in flax varieties. The variety RLC-92 (54.82\%) exhibited the highest linolenic acid followed by RLC-134 (53.01\%), R-552 (52.41\%), R-4140 (51.14\%), RLC-122 (51.08\%) and GS-64 (50.49\%). All oil and fatty acid composition expressed high heritability with moderate genetic advance implies that selection per se will be rewarding for these traits. It can be suggested from the present study that increase in oil content will enhances the linolenic acid of flax varieties.

\section{Acknowledgements}

We gratefully acknowledge the help and support provided by Directorate of Oilseed Research, Hyderabad.

\section{References}

Baydar, H., \& Turgut, I. (1999). Variations of fatty acid composition according to some morphological and physiological properties and ecological regions in oilseed plants. Turkish J. Agric. For, 23, 81-86.

Bayrak, A., Kiralan, M., Ipek, A., Arslan, N., Cosge, B., \& Khawar, K. M. (2010). Fatty acid composition of linseed (Linum usitatissimum L.) genotypes of different origin cultivated in Turkey. Biotechnol. \& Biotechnol. Eq., 24(2), 1836-1842. http://dx.doi.org/10.2478/v10133-010-0034-2

Bean, L. D., \& Leeson, S. (2002). Fatty acid profiles of 23 samples of flaxseed collected from commercial feed mills in Ontario. J. Appl. Poult. Res., 11, 209-211. http://dx.doi.org/10.1093/japr/11.2.209

Bhatty, R. S. (1995). Nutrient composition of whole flax seed and flax seed meal. In S. C. Cunnane \& L. U. Thompson (Eds.), Flaxseed in Human Nutrition (pp. 22-42). AOCS Press, Champaign, USA.

Bloedon, L. T., \& Szapary, P. O. (2004). Flaxseed and cardiovascular risk. Nutr. Rev., 62(1), 18-27.

Chen, J., Stavro, P. M., \& Thompson, L. U. (2002). Dietary flaxseed inhibits human breast cancer growth and metastasis and down regulates expression of insulin-like growth factor and epidermal growth factor receptor. Nutr. Cancer., 43(2), 187-192.

Chen, J., Wang, L., \& Thompson, L. U. (2006). Flaxseed and its components reduce metastasis after surgical 
excision of solid human breast tumor in nude mice. Cancer Lett., 234(2), 168-175.

Choo, W. S., Brich, J., \& Dufour, J. P. (2007). Physiochemical and quality characteristics of cold-pressed flaxseed oils. J. Food Composition and Analysis., 20, 202-211.

Diederichsen, A., \& Fu, Y. B. (2008). Flax genetic diversity as the raw material for future success. International Conference on Flax and Other Bast Plants ID., 51, 271-280.

Dwivedi, C., Natarajan, K., \& Matthees, D. P. (2005). Chemopreventive effects of dietary flaxseed oil on colon tumor development. Nutr. Cancer., 51(1), 52-58.

El-Beltagi, H. S., Salama, Z. A., \& El-Hariri, D. M. (2007). Evaluation of fatty acids profile and the content of some secondary metabolites in seeds of different flax cultivars (Linum usitatissimum L.). Gen. Appl. Plant Physiol., 33(3-4), 187-202.

El-Beltagi, H. S., Salama, Z. A., \& El-Hariri, D. M. (2011). Variation in oil and some phytochemical contents in flaxseed cultivars (Linum usitatissimum L.). EJEAFChe., 10(8), 2711-2721.

Gill, K. S. (1987). Linseed (pp. 301-312). Publications and Information Division, ICAR, New Delhi.

Graef, G. L., Fehr, W. R., Miller, L. A., Hammond, E. G., \& Clanzlo, S. R. (1988). Inheritance of fatty acid composition in a soybean mutant with low linolenlc acid. Crop Sci., 28, 55-58.

Green, A. G. (1986 a). Genetic control of polyunsaturated fatty acid biosynthesis in flax (Linum usitatissimum L.) seed oil. Theor. Appl. Genet., 72, 654-661.http://dx.doi.org/10.1007/BF00289004

Green, A. G. (1986 b). A mutant genotype of flax (Linum usitatissimum L.) containing very low levels of linolenic acid in its seed oil. Canadian J. Plant Sci., 66, 499-503. http://dx.doi.org/10.4141/cjps86-068

Green, A. G., \& Marshall, D. R. (1981). Variation for oil quantity and quality in linseed (Linum usitatissimum L.). Australian J. Agric. Res., 32(4), 599-607. http://dx.doi.org/10.1071/AR9810599

Huang, S., \& Milles, D. (1996). Gamma-linolenic acid: Metabolism and its roles in nutrition and medicine. Champaign, IL, AOCS Press.

Huang, S., \& Ziboh, A. (2001). Gamma-linolenic acid: Recent advances in biotechnology and clinical applications. Champaign, IL, AOCS Press.

Krist, S., Stuebiger, G., Bail, S., \& Unterweger, H. (2006). Analysis of volatile compounds and triacylglycerol composition of fatty seed oil gained from flax and false flax. European J. Lipid Sci. Technol., 108, 48-60. http://dx.doi.org/10.1002/ejlt.200500267

Lidefelt, J. O. (2007). Handbook Vegetable Oils and Fats (pp. 96-97). Alfaprint, Sweden.

Luhs W., \& Friedt, W. (1994). Non-food uses of vegetable oils and fatty acids. In D. J. Murphy (Ed.), Designer oil crops (pp. 73-130). VCH, Weinheim.

Manku, M. S., Horrobin, D. F., Huang, Y. S., \& Morse, N. (1983). Fatty acids in plasma and red cell membranes in normal humans. Lipids., 18, 906-908.

Prasad, K. (1997). Dietary flax seed in prevention of hypercholesterolemic atherosclerosis. Atherosclerosis., $132(1), 69-76$.

Rajwade, A. V., Arora, R. S., Kadoo, N. Y., Harsulkar, A. M., Ghorpade, P. B., \& Gupta, V. S. (2010). Relatedness of Indian flax genotypes (Linum usitatissimum L.): An Inter-Simple Sequence Repeat (ISSR) primer assay. Mol. Biotechnol., 45, 161-170. http://dx.doi.org/10.1007/s12033-010-9256-7

Robbelen, G., Downey, R. K., \& Ashi, A. (1989). Oil Crops of the World. New York: McGraw-Hill Inc.

Simopoulos, A. P. (2002). The importance of the ratio of omega-6/omega-3 essential fatty acids. Biomedicine and Pharmacotheraphy., 56, 365-379.

Thompson, L. U., Rickard, S. E., Orcheson, L. J., \& Seidl, M. M. (1996). Flaxseed and its lignan and oil components reduce mammary tumor growth at a late stage of carcinogenesis. Carcinogenesis, 17(6), 1373-1376. http://dx.doi.org/10.1093/carcin/20.9.1831

Van-Ruth, S. M., Shaker, E. S., \& Morrissey, P. A. (2001). Influence of methanolic extracts of soybean seeds and soybean oil on lipid oxidation in linseed oil. Food Chem., 75(2), 177-184.

Visentainer, J. V., De Souza, N. E., Makoto, M., Hayashi, C., \& Franco, M. R. B. (2005). Influence of diets enriched with flaxseed oil on the $\alpha$-linolenic, eicosapentaenoic and docosahexaenoic fatty acid in Nile tilapia (Oreochromis niloticus). Food Chem., 90, 557-560. 
Wang, B., Li, D., Wang, L. J., Huang, Z. G., Zhang, L., Chen, X. D., \& Mao, Z. H. (2007). Effect of moisture content on the physical properties of fibered flaxseed. Int. J. Food Eng., 3(5), 1-11.

Wang, L., Chen, J., \& Thompson, L. U. (2005). The inhibitory effect of flaxseed on the growth and metastasis of estrogen receptor negative human breast cancer xenograftsis attributed to both its lignan and oil components. Int. J. Cancer., 116(5), 793-798. http://dx.doi.org/10.1002/ijc.21067

\section{Copyrights}

Copyright for this article is retained by the author(s), with first publication rights granted to the journal.

This is an open-access article distributed under the terms and conditions of the Creative Commons Attribution license (http://creativecommons.org/licenses/by/3.0/). 